\title{
Life cycle traits of Philodina roseola Ehrenberg, 1830 (Rotifera, Bdelloidea), a model organism for bioassays
}

\author{
RAQUEL A. MOREIRA ${ }^{1}$, ADRISLAINE S. MANSANO ${ }^{1}$ and ODETE ROCHA ${ }^{1,2}$ \\ ${ }^{1}$ Post-Graduate Program of Ecology and Natural Resources, Federal University of São \\ Carlos, Rodovia Washington Luis, Km 235, 13565-905 São Carlos, SP, Brazil \\ ${ }^{2}$ Department of Ecology and Evolutionary Biology, Biological Sciences and Health Center, Federal \\ University of São Carlos, Rodovia Washington Luis, Km 235, 13565-905 São Carlos, SP, Brazil
}

Manuscript received on January 19, 2015; accepted for publication on May 14, 2015

\begin{abstract}
This paper describes experimental results on the life cycle of the rotifer Philodina roseola cultured in the laboratory. Detailed information on life-cycle parameters of a certain species provides a deep understanding and contributes to a better knowledge of the role of the species in the community, besides providing data that are basic to other ecological investigations such as secondary production estimates and knowledge for applications such as its utilization as test-organism in ecotoxicological studies. The average duration of embryonic development of $P$. roseola was $23.88 \mathrm{~h}$, the age at maturity of primipara was 3.5 days and the maximum lifespan was 23 days. The average size of the rotifer neonate was $198.77 \mu \mathrm{m}$, the mean size of primipara was $395.56 \mu \mathrm{m}$ and for adults $429.96 \mu \mathrm{m}$. The average fecundity was 1.22 eggs per female per day and the mean number of eggs produced per female during the entire life was 22.33 . The deceleration of somatic growth from the start of the reproductive stage represents a trade-off between growth and reproduction that is often seen in micrometazoans. The life history of $P$. roseola follows the strategy of other bdelloid species characterized by a rapid pre-reproductive development and canalization of most assimilated energy to reproduction after reaching maturity. The differences observed in total fecundity and longevity between our $P$. roseola cultures and those from previous studies were probably due to differences of intrinsic adaptation of this species ecotypes to the conditions of their natural environments.
\end{abstract}

Key words: rotifer, embryonary development, growth, fecundity, longevity.

\section{INTRODUCTION}

A detailed knowledge of the life-cycle of Philodina roseola, a benthic micro-invertebrate species, is particularly valuable as this species displays high genetic variability among clones evolving asexually and sometimes constituting sympatric complex of

Correspondence to: Raquel Aparecida Moreira

E-mail: raquel.moreira87@yahoo.com.br cryptic species (Birky Jr. et al. 2005). P. roseola has been used as a model for several types of studies, both biological, ecological and ecotoxicological (Schaefer and Pipes 1973, Gladyshev and Meselson 2008, Allinson et al. 2011).

Studies on population dynamics and the functional role of small organisms in natural environments will depend greatly on previous detailed information on species life cycle traits, and 
physiological responses of local populations. Such information is also essential for its employment as test organisms in ecotoxicological bioassays, or for environmental quality monitoring (Moreira et al. 2015, Forbes et al. 2010), since the response can be clone specific (Gabaldón et al. 2013). Furthermore, life-cycle research on rotifers can provide fundamental data, essential to analyzing the rates of processes such as ingestion, assimilation, secondary production or nutrient excretion (SantosWisniewski et al. 2006).

The growth, reproduction and survival of the micro-invertebrates are influenced by a wide range of external factors. Among these, food availability and temperature are the most important, with temperature being especially relevant to the duration of the developmental stages and food availability to reproductions (Bottrell et al. 1976).

Life-cycle variables of a given species are also crucial to the interpretation of its biological and ecological behavior in specific habitats and, beyond this, to its geographical distribution as a whole (Güntzel et al. 2003). Regarding the body structure and growth of species of the Phylum Rotifera, these invertebrates, despite having an alleged segmentation of the body are not really segmented because the apparent segments are not originated from metamerization. The division marks are actually local folds or shrinkage of the organism and possess a body cavity filled with liquid (pseudocoel), as do all blastocoelomates, with complete gut and a syncytial body wall, but with a fixed number of nuclei (eutely). Thus, these organisms grow by enlargement of the syncytium, without multiplication of nuclei (Ruppert and Barnes 1996).

There are about 460 known species of the Subclass Bdelloidea (Segers 2007), found in a variety of habitats around the world (Mayr 1963, Bell 1982). However, little is recorded about the biology and ecology of species in this Subclass. Most bdelloid rotifers are free-living, found in profusion in freshwater bodies and in permanently or periodically damp places (Donner 1965, Ricci 1987, Wallace and Snell 1991, Wallace et al. 2006).

Bdelloid rotifers possess two remarkable features that attract the interest of scientists worldwide (Fontaneto et al. 2007). The first is their ability to live in any aquatic habitat, even a short-lived one, because these rotifers can survive desiccation by entering into a dormant state called anydrobiosis (Ricci et al. 2001, 2007, Ricci and Caprioli 2005). The second is that Bdelloidea, in which male organisms are absent, appears to have evolved without sexual reproduction. This subclass is, in fact, the largest, oldest and most diverse multicellular taxon for which there is convincing morphological, cytological and molecular evidence of long-term asexual evolution (Mark Welch and Meselson 2000, Mark Welch et al. 2004).

In the dormant phase, an individual bdelloid represents an easily dispersing propagule capable of colonizing any suitable new habitat. Any such propagule can give rise to a whole new population, given that sexual partners are not required (indeed, do not exist). Hence, in theory, a given species of this group of rotifers may be found in any habitat with adequate conditions, anywhere in the world. It is normally assumed that species in the subclass Bdelloidea are cosmopolitan (Fontaneto et al. 2006).

Species of the genus Philodina have biological characteristics that immediately recommend them as environmental test organisms (Buikema et al. 1974, Hagen et al. 2009, 2010, Allinson et al. 2011). Adult individuals are small, they reproduce only by parthenogenesis, have high fecundity and the life-cycle is short. Thus, a very large number of individuals can be produced for bioassays in a short time, with few problems and low costs, and by cloning, it is feasible to have thousands of genetically identical animals within the period of an experiment. Apart from being easily generated in large numbers, Philodina spp. 
are highly representative of aquatic habitats in general, being found in a wide variety of freshwater bodies including the lakes, ponds, swamp and marsh-water, rivers, streams and springs. They are also present in mosses, liverworts and lichens, bromeliad hearts, roadside puddles and ditches, moist organic matter, soil and even in wastewater treatment tanks (Wallace and Snell 2010). Although the genus Philodina includes species that are primarily benthic creeping forms, some species are also semi-pelagic thriving in the water column for food, heavily relying on its ciliate corona to swim freely (Hochberg and Litovaitis 2000).

The purpose of this study was to gather detailed information on the life-cycle of Philodina roseola. Detailed information on life cycles of rotifers may help to differentiate among cryptic species in addition to provides a deep understanding and contributes to a better knowledge of the role of the species in the community, besides providing data that are basic to other ecological investigations, such as secondary production estimates and knowledge applications as its utilization as testorganism in ecotoxicological studies. A deep understanding of species biological and ecological requirements is also essential for applications such as growing rotifers as aquaculture live-feed, or as test-organisms for ecotoxicological studies.

\section{MATERIALS AND METHODS}

\section{MAINTENANCE OF ROTIFER STOCK CULTURE}

Specimens of Philodina roseola Ehrenberg, 1830 (Rotifera, Bdelloidea) were collected from glassfiber experimental tanks of 10,000 L capacity, maintained at the Federal University of São Carlos (São Carlos, SP, Brazil) Aquaculture Station. Zooplankton samples were collected with a plankton net of $68 \mu \mathrm{m}$ mesh and stored in wide-mouth polythene bottles, sorted and identified according to Koste and Shiel (1986) and Koste and Terlutter (2001), in order to isolate individuals of the species $P$. roseola (see Supplementary Material).
The culture medium consisted of reconstituted water prepared as recommended by the Brazilian Association of Technical Normalization (ABNT 2005): $0.03 \mathrm{gL}^{-1} \mathrm{CaSO}_{4} .2 \mathrm{H}_{2} \mathrm{O}, 0.061 \mathrm{~g} \mathrm{~L}^{-1}$ $\mathrm{MgSO}_{4} .7 \mathrm{H}_{2} \mathrm{O}, 0.048 \mathrm{~g} \mathrm{~L}^{-1} \mathrm{NaHCO}_{3}$ and $0.002 \mathrm{gL}^{-1}$ $\mathrm{KCl}$ were dissolved in $1 \mathrm{~L}$ distilled water and this medium had $\mathrm{pH}$ adjusted to 7.0-7.8, hardness to 40-48 $\mathrm{mg} \mathrm{CaCO}_{3} \mathrm{~L}^{-1}$ and electrical conductivity to $160 \mu \mathrm{Scm}^{-1}$.

Stock cultures of $P$. roseola were maintained at high densities (mean value of 116 ind. $\mathrm{mL}^{-1}$ ) in 50$250 \mathrm{~mL}$ glass beakers, at controlled temperature of $25 \pm 1^{\circ} \mathrm{C}$, with a photoperiod of $16 \mathrm{~h}$ light: $8 \mathrm{~h}$ dark. To prevent evaporation of the culture medium, the beakers were sealed with plastic film. Every 76 hours, as proposed by Hagen et al. (2009), the water and food were renewed. The rotifers were fed on a suspension of the alga Raphidocelis subcapitata, grown in CHU-12 medium (Müller 1972), at a density of $1 \times 10^{5}$ cells $\mathrm{mL}^{-1}$. The lifecycle study was carried out on individual rotifers, each organism being observed in $3.0 \mathrm{~mL}$ of the culture medium, in a $9-\mathrm{cm}$ diameter watch glass kept inside a Petri dish $(110 \times 15 \mathrm{~mm})$ with a lid to prevent evaporation. The animals were observed under a stereo microscope at magnification 50x and were handled gently with the aid of Pasteur pipettes. The culture medium, prepared from reconstituted water, was changed every day.

\section{EMBRYONIC DEVELOPMENT}

The duration of embryonic development of $P$. roseola was determined by observing the main transformations that occurred in the progeny from the moment when eggs appeared in the females. In addition, the duration (in hours) of each stage of the embryonic development was recorded. The basic method was as follows:

Sexually immature females were taken from the stock culture and kept in culture medium in watch-glasses. When they were ready to produce 
eggs (i.e. just before becoming primiparas), 9 females were collected and individually placed in watch glasses containing $3 \mathrm{~mL}$ of culture medium.

\section{POST-EMBRYONIC DEVELOPMENT}

Nine neonates were placed on separate $9-\mathrm{cm}$ watch glasses, in $3 \mathrm{~mL}$ of culture medium, which were maintained in Petri dishes $(110 \times 15 \mathrm{~mm})$ and cultured under the same conditions as for the stock culture of $P$. roseola. Measurements were made under the stereoscopic microscope equipped with a micrometer scale, from head to foot, so that the length of the animal was recorded each 3 hours, in the fully stretched position. In relation to the measurements of the rotifer size, this was performed each 3 hours since $P$. roseola neonate eclosion until its first reproduction, which had duration of $3.5 \pm$ 3.11 days.

The growth curve was fitted to the data by the Von Bertalanffy equation, the Ford-Walford transformation being used to establish the initial parameter L (Sparre and Venema 1998):

$$
\mathrm{Lt}=\mathrm{L} \infty\left[1-\mathrm{e}^{-\mathrm{K}(\mathrm{t}-\mathrm{t})}\right]
$$

Where $\mathrm{Lt}=$ length at time $\mathrm{t}(\mathrm{mm}), \mathrm{L}=$ maximum length $(\mathrm{mm}), \mathrm{K}=$ growth rate constant $\left(\mathrm{d}^{-1}\right), \mathrm{e}=$ base of natural logarithms, $\mathrm{t}_{0}=$ theoretical time before birth when model extrapolates to zero length.

The age at first reproduction was taken as the time elapsed between the birth of the recently born rotifer and that of its first progeny. Observations were recorded every 3 hours.

To determine the fecundity, the number of eggs produced daily by each female was counted, summing the observations made each 6 hours, and the progeny hatched in each of these intervals was removed at the time of observation. The lifespan (duration of life-cycle) was taken as the time elapsed between the birth and death of the organism, observations being made initially at 3-hour intervals and, following the stabilization of the growth rate, at 6-hour intervals.

\section{RESULTS}

The variation in the size of the individual rotifers throughout the life-cycle of is illustrated in Figure 1 , where it can be seen that the body length altered substantially during the first few days of life. It is noted that, after a period of fast exponential growth, the rate slowed perceptibly from around the fourth day and the body length continued increasing slowly towards the asymptotic maximum. However, it should not be forgotten that these data represent individuals growing in a medium with abundant food (Raphidocelis subcapitata) and an ideal controlled temperature of $25 \pm 1^{\circ} \mathrm{C}$.

The mean period of embryonic development lasted for $23.88 \pm 3.82 \mathrm{~h}$. The mean body size of a female rotifer and the mean total fecundity and other variables recorded for the life-cycle of $P$. roseola are presented in Table I. The mean daily fecundity for each day covering the lifespan of $P$. roseola is plotted in Figure 2.

\section{DISCUSSION}

Philodina roseola can be described as a fast-developing micrometazoon, on the basis of its high growth-rate and the short time taken to reach its maximum size. The slowing of its somatic growth, coincident with the start of reproduction suggests a trade-off between growth and reproduction that

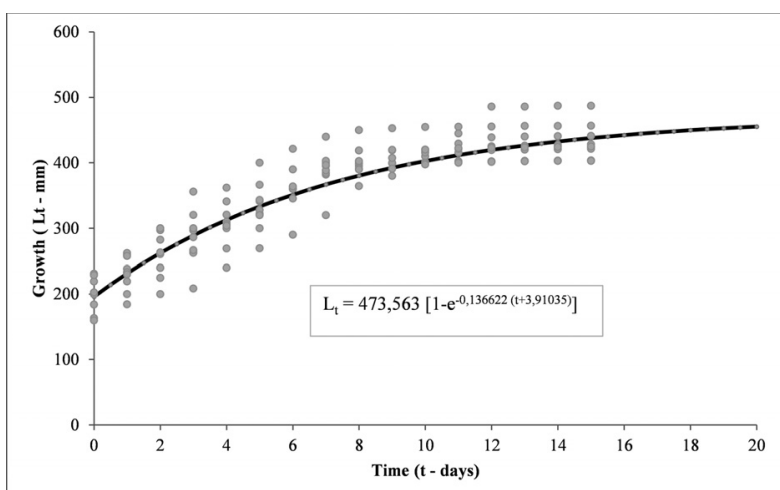

Figure 1 - Growth curve for individual Philodina roseola cultured at $25 \pm 1{ }^{\circ} \mathrm{C}$ and fed on the chlorophycean microalga Raphidocelis subcapitata at a density of $1 \times 10^{5}$ cells $\mathrm{mL}^{-1}$. The data points show the observed values for 9 replicate animals. 
TABLE I

Life-cycle variables (mean \pm standard deviation: $\mathbf{n}=9$ ) of the rotifer Philodina roseola cultured in the laboratory at $25 \pm 1^{\circ} \mathrm{C}$, under a photoperiod of $16 \mathrm{~h}$ light: $8 \mathrm{~h}$ dark, and fed on a suspension of Raphidocelis subcapitata at $10^{5}$ cells $\mathrm{mL}^{-1}$.

\begin{tabular}{lc}
\hline Life cycle parameters & Variable \\
\hline Length of adult $(\mu \mathrm{m})$ & $429.96 \pm 28.12$ \\
Length of newborn $(\mu \mathrm{m})$ & $198.77 \pm 25.88$ \\
Length at first reproduction $(\mu \mathrm{m})$ & $395.56 \pm 19.44$ \\
Minimum length at first reproduction $(\mu \mathrm{m})$ & 360.00 \\
Total fecundity (eggs per female in whole life) & $22.33 \pm 2.29$ \\
Mean fecundity (eggs per female per brood) & $1.22 \pm 0.44$ \\
Maximum longevity (days) & 23.00 \\
Mean longevity (days) & $19.33 \pm 2.06$ \\
Duration of embryonic development (hours) & $23.88 \pm 3.82$ \\
Age at first reproduction (days) & $3.5 \pm 3.11$ \\
\hline
\end{tabular}

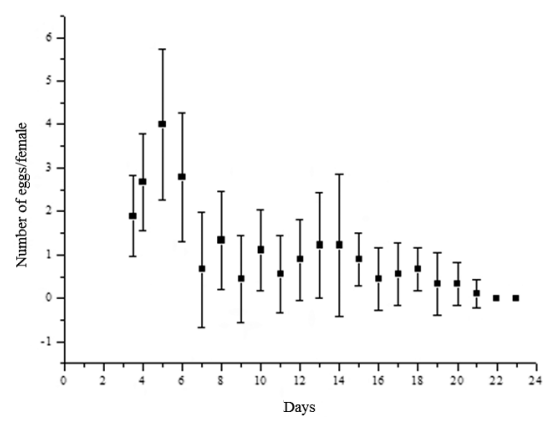

Figure 2 - Daily fecundity (mean \pm standard deviation) of $P$. roseola during its life-cycle, when cultured at $25 \pm 1{ }^{\circ} \mathrm{C}$ with abundant live algae as food. Data points represent mean values for 9 isolated individuals.

micrometazoans often make. In this case, species invest the available energy in body growth until reaching the first reproduction and from that time onwards it allocates all the energy into reproduction (Snell and King 1977).

In the case of other group of freshwater invertebrates, the Cladocera, Dumont (1987) reported that some species invest energy in growth throughout their life and consequently have low rates of reproduction, while others allocate most of their energy to reproduction and thus have short lifespans. In the present study, it was found that the growth of the rotifer under study is fast until the third day of its life (age of first reproduction). Although it continues to grow after the first brood, $P$. roseola then invests more energy in reproduction than in body growth and the growth rate falls considerably, around day 5.

Lebedeva and Gerasimova (1985) stated that the effects of temperature on the duration of the reproductive period and the total egg production per female $P$. roseola are clearly evident. Those authors also followed the daily fecundity throughout the life-cycle of this species and concluded that it differs completely between high and low temperatures. Thus, at $26{ }^{\circ} \mathrm{C}$, there was a fast rise in fecundity around day 5 , while at $14{ }^{\circ} \mathrm{C}$ low fecundity was observed without any pronounced period of peak egg production, whereas reproduction was inhibited at $32{ }^{\circ} \mathrm{C}$. The authors concluded that, while $P$. roseola tolerates a wide range of temperatures, growth being possible from $14{ }^{\circ} \mathrm{C}$ to $32^{\circ} \mathrm{C}$ and that the interval between $20{ }^{\circ} \mathrm{C}$ and $26{ }^{\circ} \mathrm{C}$ is the ideal range for growth and reproduction of this species.

The results of this study for longevity, fecundity, age and best culture temperature are compared in Table II with the published data on various rotifer species of the Subclass Bdelloidea. The age at first reproduction for $P$. roseola coincided with that of Adineta vaga, Habrotrocha constricta and Macrotrachela inermis, cultured at $24^{\circ} \mathrm{C}-25^{\circ} \mathrm{C}$. 
TABLE II

Comparison between lifespan (days), total fecundity, age at first reproduction and culture temperature of Philodina roseola, observed in this study, and variables taken from the literature for 19 rotifer species.

\begin{tabular}{lccccc}
\hline Species & Lifespan & $\begin{array}{c}\text { Total } \\
\text { fecundity }\end{array}$ & $\begin{array}{c}\text { Age at first } \\
\text { reproduction }\end{array}$ & Temperature $\left({ }^{\circ} \mathbf{C}\right)$ & Source \\
\hline Adineta vaga & 17 & 14 & 3 & 24 & Ricci 1983 \\
Embata laticeps & 27 & 20 & 4 & 24 & Ricci 1983 \\
Habrotrocha constricta & 38 & 21 & 3 & 24 & Ricci 1983 \\
Habrotrocha elusa vegeta & 32 & 22 & 2 & 24 & Ricci 1983 \\
Habrotrocha sylvestris & 40 & 26 & 4 & 24 & Ricci 1983 \\
Macrotrachela inermis & 31 & 24 & 3 & 24 & Ricci 1983 \\
Macrotrachela insolita & 76 & 22 & 9 & 24 & Ricci 1983 \\
Otostephanos torquatus & 45 & 10 & $7-8$ & 24 & Ricci 1983 \\
Philodina roseola & 20 & 23 & 3 & 25 & Present study \\
Philodina roseola & 27 & 35 & 3 & 24 & Ricci 1983 \\
Philodina vorax & 22 & 13 & 6 & 22 & Ricci and Fascio 1995 \\
\hline
\end{tabular}

For laboratory cultured rotifers of the subclass Bdelloidea, the life-cycle lasted approximately 30 days, during which they produced, on average, around 20-35 eggs (Ricci 1983), although they were fed on different foods (Escherichia coli, some species of yeast, particulate organic matter). High food concentrations and supplementing algal diet with bacteria as in the latter study may improve rotifer nutrition, thus increasing fecundity and longevity. This could be the reason for the lower fecundity found for $P$. roseola in our study as compared to the same species performance in the study of Ricci (1983).

In another study Ricci (1984) tested different methods for culturing some bdelloid rotifers. This author found that by adding a variety of food sources to the culture medium was an efficient strategy, and that bacteria and yeast are usually adequate foods for bdelloid rotifers, having optimized growth of the tested species. Nevertheless, she calls attention to the fact that these results cannot be generalized $g$ that two clones of the same species, although morphologically identical can have different requirements and preferences, especially when coming from environments with different climates, as pointed out by Erman (1956), Pourriot (1977) and Stemberger (1981).
In response to disturbance (e.g. evaporation of available water), bdelloids can enter the dormant state of anhydrobiosis, returning to the active state when the conditions in the surroundings become suitable again.

The recovery rate of these organisms depends on the species (Ricci 1998), on the duration of the phase of desiccation (Caprioli et al. 2004) and on the age of the rotifers at the start of dormancy. In any case, the dormant period represents a "blank" phase in the life of bdelloids, in the sense that they return to the life-cycle at the point where they left it, without reflecting the time they remained dormant.

The quality and quantity of food are controlling factors for secondary production in aquatic ecosystems (Santos et al. 2010, Rajendiran and Subramanian 2007, Snell 2014) and an increase in the amount of food available leads to a rise in egg production (Santos et al. 2006, Strojsová et al. 2009). According to Sarma et al. (2005), the greater availability of food and higher temperatures in tropical, than in temperate regions favor the Rotifera, which are found in the majority of freshwater habitats and are often the group of zooplankton with the highest secondary production, by virtue of their short generation time and numerical dominance (Starkweather 1987, Walz 1997, 
Wallace 2002, Wallace and Snell 2010, Snell 2014), in spite of their small biomass at any given moment (Ruttner-Kolisko 1972).

In a recent study Gabaldón et al. (2013) aiming to understand the mechanisms that could explain the coexistence of cryptic species obtained results that challenge the conventional theory of niche differentiation. The authors cultured two cryptic rotifer species, Brachionus plicatilis and B. manjavacas, focusing at three fundamental ecological characteristics: (1) a functional response represented by the filtering rate, (2) the tolerance to starvation assessed by growth and reproduction performance and (3) vulnerability to predation. The authors concluded that there were no large differences between $B$. plicatilis and B. manjavacas in relation to these traits, thus evidencing the existence of considerable niche overlap among these two species. Considering the frequent occurrence of cryptic species among bdelloid rotifers, and that most of what is known about the biology and ecology of rotifers is based on the research of planktonic rotifers in temperate zones (Ricci 2001), it is believed that even species described as cosmopolitan, such as $P$. roseola, may have very different strategies and life-histories in tropical conditions.

Therefore, the study of the biology of rotifer species should go outside the laboratory, into their natural habitats, particularly into tropical water bodies, where they are very often dominant among macro-invertebrates.

Whereas most toxicity testes with rotifers utilize species of the genus Brachionus (Monogononta) as test-organisms, the reason why in our study we suggest the species Philodina roseola (Digononta, Bdelloidea) as a test organism is because we believe that ecotoxicological studies with rotifers must include and standardize procedures for many species considering that the response to toxicants are species-specific (Dahms et al. 2011, Moreira et al. 2015). Taking into account that a toxicological evaluation in aquatic ecosystems requires a set of species representative of a variety of ecological niches, the use of $P$. roseola, a benthic species will be relevant since most used rotifer species belong to the plankton, as mentioned before. Also, species of the genus Philodina fullfil the biological characteristics recommended for a test organism (Buikema et al. 1974, Hagen et al. 2009, 2010, Allinson et al. 2011), besides occurring in a variety of freshwater environments (Wallace and Snell 2010, Sharma and Sharma 2012). In freshwater reservoirs of Southern Brazil, for example they are frequent, developing large populations (SouzaSoares et al. 2011, Garraffoni and Lourenço 2012).

The life history of Philodina roseola follows the general strategy of other bdelloid species characterized by a rapid pre-reproductive development and canalization of most assimilated energy to reproduction after reaching maturity. The differences observed in total fecundity and longevity between our $P$. roseola cultures and those from previous studies were probably due to differences in the nutrition of the laboratory cultures and to differences of intrinsic adaptation of the species ecotypes to the conditions of their original natural environments. $P$. roseola laboratory populations fulfilled the necessary requirements as a test-organism as: high survival rate, fast growth and high fecundity.

\section{ACKNOWLEDGMENTS}

We are grateful to MSc Timothy J.C. Roberts for translation assistance, to Dr. José Roberto Verani for helping with the curve fitting, to Dr. Natália Felix Negreiros, for the initial identification of the species used in this study and to Dr. Nataliia Iakovenko for confirming the species identity and to the (Coordenação de Aperfeiçoamento de Pessoal de Nível Superior (CAPES), for the financial support. 


\section{RESUMO}

Este artigo descreve os resultados experimentais do ciclo de vida do rotífero Philodina roseola, cultivado em laboratório. Informações detalhadas sobre os parâmetros do ciclo de vida de uma dada espécie permitem um entendimento aprofundado e contribuem para uma melhor compreensão do papel dessa espécie na comunidade, além de fornecer dados que são básicos para outras investigações ecológicas como, por exemplo, a estimativa da produção secundária, e aplicações como sua utilização como organismo-teste em estudos ecotoxicológicos. A duração média do desenvolvimento embrionário de $P$. roseola foi 23,88 horas, a idade de maturação das primíparas foi de 3,5 dias e a longevidade máxima foi de 23 dias. O tamanho médio de rotíferos recém-nascidos foi de 198,77 $\mu \mathrm{m}$, o tamanho médio de primípara foi 395,56 $\mu \mathrm{m}$ e dos adultos de 429,96 $\mu \mathrm{m}$. A fecundidade média foi de 1,22 ovos por fêmea por dia e o número médio de ovos produzidos por fêmea durante a vida inteira foi 22,33. A desaceleração do crescimento somático, desde o início da fase reprodutiva representa um trade-off entre crescimento e reprodução que é visto frequentemente em micrometazoários. A história de vida de $P$. roseola segue a estratégia de outras espécies de bdeloídeos, caracterizada por um rápido desenvolvimento pré-reprodutivo e canalização de mais energia assimilada para a reprodução após atingirem a maturidade. As diferenças observadas na fecundidade total e longevidade entre nossas culturas de $P$. roseola e as de estudos anteriores foram, provavelmente, devido a diferenças de adaptação intrínseca de ecótipos desta espécie para as condições de seus ambientes naturais.

Palavras-chave: rotífero, desenvolvimento embrionário, crescimento, fecundidade, tempo de vida.

\section{REFERENCES}

ABNT - ASSOCIAÇÃO BRASILEIRA DE NORMAS TÉCNICAS. 2005. Ecotoxicologia aquática - Toxicidade crônica Método de ensaio com Ceriodaphnia spp. (Crustacea, Cladocera). NBR 13373. Rio de Janeiro.

ALlinson G, HAGEN T, SALZMAN S, WightwiCK A AND NUGEGODA D. 2011. Effect of increasing salinity on the acute toxicity of a commercial endosulfan formulation to the bdelloid rotifer Philodina acuticornis odiosa. Environ Toxicol Chem 93: 722-728.
BELL G. 1982. The Masterpiece of Nature: the Evolution and Genetics of Sexuality. London: University of California Press, $635 \mathrm{p}$.

Birky JCW, WOLF C, MAUGHAN H, HERBERTSON L AND HENRY E. 2005. Speciation and selection without sex. Hydrobiol 546: 29-45.

Bottrell HH, DunCAN A, Gliwicz ZM, Herzig A, HILLBRICHT-ILKOWSKA A, KURASAWA H, LARSSON P AND WEGLENSKA T. 1976. A review of some problems in zooplankton production studies. Brow J Zool 24: 419-456.

BUIKEMA AL, CAIRNS J AND GAIL SULLIVAN W. 1974. Development and assessment of acute bioassay techniques for the littoral rotifer, Philodina acuticornis: completion report. Office of Water Resources Research Bulletin n. 71, Virginia: Virginia Polytechnic Institute and State University, $38 \mathrm{p}$.

CAPRIOLI M, KATHOLM AK, MELONE G, RAMLOV H, RICCI C AND SANTO N. 2004. Trehalose in desiccated rotifers: a comparison between a bdelloid and a monogonont species. Comp Biochem Phys A 139: 527-532.

DAhms HU, HagiwaraC A AND JAE-SEOnG L. 2011. Ecotoxicology, ecophysiology, and mechanistic studies with rotifers. Aquat Toxicol 101: 1-12.

DONNER J. 1965. Ordnung Bdelloidea. Berlin: AkademieVerlag, 297 p.

DUMONT HJ. 1987. A population study of Scapholeberis rammneri Dumont and Pensaert (Cladocera:Daphniidae). Hydrobiol 145: 275-284.

ERMAN LA. 1956. Feeding habits of Rotifers from the quantitative aspect. Zool Zh 35: 965-971.

FontANETO D, FiCETOLA GF, AMBROSINI R AND RICCI C. 2006. Patterns of diversity in microscopic animals: are they comparable to those in protists or in larger animals? Global Ecol Biogeogr 15: 153-162.

FONTANETO D, HERniou EA, BARRACLOUGH TG AND RICCI C. 2007. On the Global Distribution of Microscopic Animals: New Worldwide Data on Bdelloid Rotifers. Zool Stud 46: 336-346.

FORBES VE, OLSEN M, PALMQVIST A AND CALOW P. 2010. Environmentally sensitive life-cycle traits have low elasticity: implications for theory and practice. Ecol Appl 20: 1449-1455.

GABALdÓn C, MONTERO-PAU J, SERRA M AND CARMONA MJ. 2013. Morphological similarity and ecological overlap in two rotifer species. Plos One 8 (2): e57087.

GARRAFFONI ARS AND LOURENÇO AP. 2012. Synthesis of Brazilian Rotifera: an updatedlist of species. Check List 8 (3): 375-407.

GLADYSHEV E AND MESELSON M. 2008. Extreme resistance of bdelloid rotifers to ionizing radiation. PNAS 105(13): 5139-5144.

GÜNTZEL AM, ROCHA O AND MATSUMURA-TUNDISI T. 2003. Life cycle of Macrothrix flabelligera Smirnov, 1992 
(Cladocera, Macrothricidae) recently reported for the Neotropical region. Hydrobiol 490: 87-92.

HAGEN T, Allinson G, Wightwick A AND NugEGOdA D. 2009. Assessing the performance of a bdelloid rotifer Philodina acuticornis odiosa acute toxicity assay. B Environ Contam Tox 82: 285-289.

Koste W AND SHIEL BRJ. 1986. Rotifera from Australian Inland Waters. I. Bdelloidea (Rotifera : Digononta). Aust J Mar Freshw Res 37: 765-92.

Koste W AND TerlutTer H. 2001. Die Rotatorienfauna einger Gewasser des Naturschutzgebietes "Heiliges Meer" im Kreis Steinfurt. Osnabrücker Naturw Mitt 27: 113-117.

LEBEDEVA LI AND GERASIMOVA TN. 1985. Peculiarities of Philodina roseola (EHRBG.) (Rotatoria, Bdelloida) - Growth and Reproduction under Various Temperature Conditions. Int Rev Gesamten Hydrobiol Hydrogr 70: 509-525.

MARK WELCH DB AND MESELSON M. 2000. Evidence for the evolution of bdelloid rotifers without sexual reproduction or genetic exchange. Science 288: 1211-1215.

MARK WelCh JL, MARK WELCH DB AND MESElson M. 2004. Cytogenetic evidence for asexual evolution of bdelloid rotifers. Proc Natl Acad Sci USA 101(6): 16181621.

MAYR E. 1963. Animal Species and Evolution. Harvard University Press: Cambridge, 797 p.

MoreIRA RA, MANSANO AS AND RochA O. 2015. The toxicity of carbofuran to the freshwater rotifer, Philodina roseola. Ecotoxicology 24: 604-615.

MÜLlER H. 1972. Wachstum and phosphatbedarf von Nitzschia actinastroides (Lemn.) v. Goor in statischer und homokontiuierliecher Kultur unter Phosphatlimitierung. Arch Hydrobiol 38: 399-484.

POURRIOT R. 1977. Food and feeding habits of Rotifera. Arch Hydrobiol Beih Ergebn Limnol 8: 243-260.

RAJENDIRAN A AND SUBRAMANIAN P. 2007. Mass production of freshwater rotifer Brachionus calyciflorus, under different diets and regimes. J Appl Aquac 19: 101 -113.

RICCI C. 1983. Life histories of some species of Rotifera Bdelloidea. Hydrobiol 104: 175-180.

RICCI C. 1984. Culturing of some bdelloid rotifers. Hydrobiol 112: 45-51.

RICCI C. 1987. Ecology of bdelloids: How to be successful. Hydrobiol 147: 117-127.

RICCI C. 1998. Anhydrobiotic capabilities of bdelloid rotifers. Hydrobiol 387/388: 321-326.

RICCI C AND CAPRIOLI M. 2005. Anhydrobiosis on Bdelloid species, populations and individuals. Integr Comp Biol 45: 759-793.

RiCCI C, CAPRIOLI M AND FONTANETO D. 2007. Stress and fitness in parthenogens: is dormancy a key feature for bdelloid rotifers?. BMC Evolutionary Biol 7: S9.
RICCI C AND FASCIO U. 1995. Life-history consequences of resource allocation of two bdelloid rotifer species. Hydrobiol 299: 231-239.

RiCCI C, MELONE G AND WALSH EJ. 2001. A carnivorous bdelloid rotifer, Abrochtha carnivora n. sp.. Invertebr Biol 120: 136-141.

RUPPERT EE AND BARNES RD. 1996. Zoologia dos Invertebrados. $6^{\mathrm{a}}$ ed., São Paulo: Editora Roca, 1028 p.

RUTTNER-KOLLISKO A. 1972. III. Rotatoria. Das zooplankton der Binnengewässer. Die Binnengewässer 26: 99-234.

SANTOS MAPF, MELÃO MGG AND LOMBARDI AT. 2006. Life history characteristics and production of Ceriodaphnia silvestrii Daday (Crustacea, Cladocera) under different experimental conditions. Acta Limnol Bras 18: 199-212.

SANTOS RM, NEGREIROS NF, SILVA LC, ROCHA O AND SANTOS-WISNIEWSKI MJ. 2010. Biomass and production of Cladocera in Furnas Reservoir, Minas Gerais, Brazil. Braz J Biol 70: 879-887.

SANTOS-WISNIEWSKI MJ, ROCHA O AND MATSUMURATUNDISI T. 2006. Aspects of the Life Cycle of Chydorus pubescens Sars, 1901 (Cladocera, Chydoridae). Acta Limnol Bras 18: 305-310.

SARMA SSS, NANDINI S AND GULATI RD. 2005. Life history strategies of cladocerans: comparisons of tropical and temperate taxa. Hydrobiol 542: 315-333.

SCHAEFER ED AND PIPES WO. 1973. Temperature and the toxicity of chromate and arsenate to the rotifer Philodina roseola. Water Res 7: 1781-1790.

SEGERS H. 2007. Annotated checklist of the rotifers (Phylum Rotifera), with notes on nomenclature, taxonomy and distribution. Zootaxa, 1564. New Zealand: Magnolia Press Auckland, 144 p.

SHARMA BK AND SHARMA S. 2012. Diversity of zooplankton in a tropical floodplain lake of the Brahmaputra river basin, Assam (Northeast India). Opusc Zool Budapest 43 (2): 187-195.

SNELL TW. 2014. Rotifers as models for the biology of aging. Int Rev Hydrobiol 99: 84-95.

SNELL TW AND KING CE. 1977. Lifespan and fecundity patterns of rotifers: the cost of reproduction. Evolution 31: 882-890.

SOUZA-SOARES F, TUNDISI JG AND MATSUMURA-TUNDISI T. 2011. Check-list de Rotifera de água doce do Estado de São Paulo, Brasil. Biota Neotrop 11(1a): 515-539.

SPARRE P AND VENEMA SC. 1998. Introduction to tropical fish stock assessment. Part 1, Manual. Rome: FAO Fisheries Technical Paper 306/1 Rev. 2, 385 p.

STARKWEATHER PL. 1987. Rotifera. In: PANDIAN TJ AND VERNBERG FJ (Eds), Animal energetics. Vol 1: Protozoa through Insecta. Orlando: Academic Press, p. 159-183.

STEMBERGER RS. 1981. A general approach to the culture of planktonic rotifers. Can J Fish Aquat Sci 38: 721-724. 
StrojsovÁ M, SUGA K, HAGIWARA A AND VRBA J. 2009. Effect of Food Quantity and Quality on Population Growth Rate and Digestive Activity in the Euryhaline Rotifer Brachionus plicatilis Müller. Int Rev Hydrobiol 94: 706719.

WALLACE RL. 2002. Rotifers: Exquisite Metazoans. Integr Comp Biol 42: 660-667.

WALlACE RL AND SNell TW. 1991. Rotifera. Chapter 8. In: THORP JH AND COVICH AP (Eds), Ecology and Classification of North American Freshwater Invertebrates. New York: Academic Press, p. 187-248.

WALlaCE RL AND SNELL TW. 2010. Rotifera. Chapter 8. In: THORP JH AND COVICH AP (Eds), Ecology and classification of North American freshwater invertebrates. Oxford: Elsevier, p. 173-235.

WALLACE RL, SNELL TW, RiCCI C AND NOGRADY T. 2006. Rotifera. Biology, Ecology and Systematics, $2^{\text {nd }}$ ed. In: SEGERS H (Ed), Guides to the identification of the microinvertebrates of the continental waters of the world. Leiden: Ghent and Backhuys Publishers, p. 299.

WALZ N. 1997. Rotifer life history strategies and evolution in freshwater plankton communities. In: STREIT B, STÄDLER T AND LIVELY CM (Eds), Evolutionary ecology of freshwater animals. Basel: Birkhäuser Verlag, p. 119-149.

\section{SUPPLEMENTARY MATERIAL}

As stated in the manuscript Philodina roseola was identified based on the descriptions of Koste and Terlutter (2001) and descriptions and taxonomical key of Koste and Schiel, 1986, using morphological characteristics only. Nevertheless, because we succeeded maintaining it in laboratory cultures we could repeatedly check its morphological characteristics, as shown in the figures bellow: trophi (1a and $1 \mathrm{~b}$ ), trophi lateral (1c), presence of two eyes, the eyes are reddish ranging to reddish brown (2a and $2 b$ ), 1 pair of spurs (3), as number of feet ( 2 pairs of feet) (4), number of caudal segments (five) (5) and head and neck clearly separated from the trunk (6) that leaded us up to this species. 